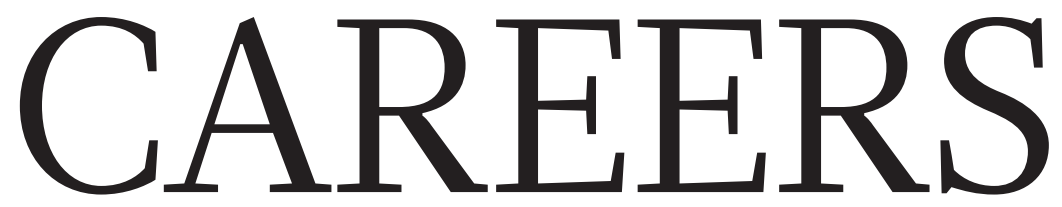

STAR STRUCK An astronomer crunches data for Hollywood p.257
LINKEDIN A beginner's guide to the networking site go.nature.com/2c4wg7v
NATUREJOBS For the latest career

listings and advice www.naturejobs.com

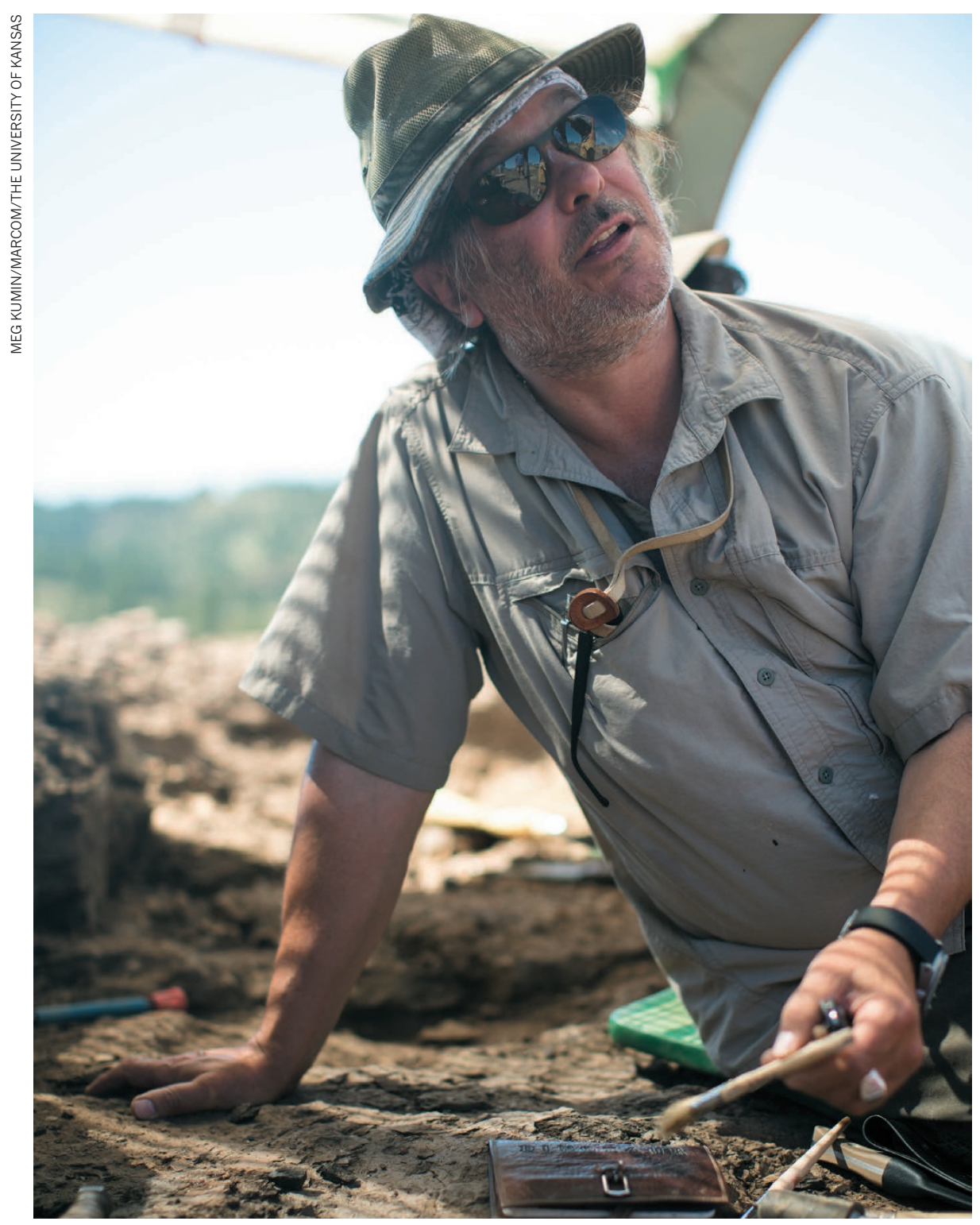

Palaeontologist David Burnham has landed on some of his best ideas while mindlessly digging for bones.

\section{Daydream and discover}

Tedious daily work might feel frustrating, but idle thoughts can drum upjust the right spark of scientific inspiration.
BY EMILY SOHN

$\mathrm{W}$ hen biologist Adrian Smith chose to study ants, he approached the field with ambitious questions and big dreams of discovering how animal societies work. The reality was much less glamorous.

To capture ant colonies to study in the lab, he digs human-sized holes and then plucks out thousands of insects, one by one. After six hours or more of this backbreaking work, Smith, who works at the North Carolina Museum of Natural Sciences in Raleigh, and his teammates sometimes discover that the queen is missing, or they've inadvertently cut her in half. They then have to start over again.

Such mind-numbing work occupies researchers' time in most specialities. By nature, science depends on intensive data collection, repetition and replication. To cope with the tedium, experienced scientists have found tricks for making the work more pleasurable, such as getting to know colleagues who are in the same trenches and keeping long-term goals in mind.

Given the intense focus required for the bulk of their work, many scientists learn to value brainless tasks that allow them to zone out and indulge in free thinking. That can lead to creative research ideas or ways to boost efficiency. Faced with day after day of doing the same thing, researchers who appreciate boredom can gain insight into their goals and priorities.

\section{SURVIVAL GAME}

Boredom is a typical part of the process of scientific discovery, which rarely happens in a day. Even when intriguing results emerge, it can take many months to write a paper, get it peer reviewed and complete multiple revisions, and then wait for publication before sharing discoveries with the world. The first step towards coping successfully can be simply to accept the drill.

"We wouldn't be on the edge of discovery if it was easy," Smith says. "Sometimes, you're in places where no one has really looked, or you're seeing something no one has seen before. To get to that point, it takes some tedious work."

At such times, it can help to remember that the work might eventually bring bursts of exhilaration or, sometimes, a real thrill of discovery, says David Burnham, a palaeontologist at the University of Kansas Biodiversity Institute \& Natural History Museum in Lawrence. He regularly digs for dinosaur bones - an experience that resembles a notorious description of war he says - it entails "long periods of boredom, interspersed with high excitement”. 
mentedbefore be even more delicate process of excavation and investigation continues.

As the hours disappear, Burnham keeps in mind the possibility that he might at any moment find a motherlode of bones or a fossil that will change everything. Equally motivating are sporadic discoveries that shed light on big questions. Sometimes, the pay-off can be huge. On one memorable dig in China, Burnham's team found a raptor that turned out to be a new species. During the monotonous fact-checking process required to verify the find, the team compared the new bones to those of a related raptor and realized that the relative had grooved teeth, which suggested that it was venomous. That realization led to a paper, published in the Proceedings of the National Academy of Sciences ${ }^{1}$ in 2010, that described the first venomous raptor ever known.

Finds such as those are rewarding enough, he says, to confer a surprisingly high tolerance for boredom or similar discomfort. "That one piece of excitement is so exhilarating," he says. "It just gets into your blood and you have to keep going."

Telling others about your grand goals can be another way to endure tedium, suggests
David Hadley, an epidemiologist in Tampa, Florida, who does both academic and industrial research. He is developing a programme that would help oncologists to settle on the best course of care for patients with cancer on the basis of treatment data from previous patients and other information such as their ages, gender and genetic variations. To get it right, he has to run a lot of computer simulations and then wait as a computer crunches data, sometimes for up to a week. Often, results reveal mistakes that need to be fixed before the next simulation can be run. "It really helps to talk to people about the big picture, not necesabout what you are trying to achieve overall," he says. "In my case, it's trying to help sick kids. That is why I'm motivated to do it."

\section{GRUNT WORK TO GROWTH}

Just as musicians need to learn scales before they can improvise, grunt work is a necessary step towards designing studies to answer big questions, adds William Stoops, a behavioural pharmacologist at the University of Kentucky in Lexington. He has spent many hours supervising research subjects as they interact with a computer to earn doses of addictive drugs, with the goal of working out what drives drug use and abuse, and finding treatments. "If you can't understand what a subject is supposed to do in a session, and you design an experiment that's just not feasible, it will fail," he says. "Every graduate student and postdoc learns this stuff from the ground up."

Frequently reminding yourself of the potential pay-off can make delayed gratification more palatable, Smith says. "It sucks until it doesn't" is a mantra that he repeated to himself on a trip this year to Florida, where he spent eight long, hot days roaming around forests getting bitten by mosquitoes while crawling on his hands and knees to look for ants. It was tough going until

\section{BEATING BOREDOM}

\section{Tunes for tedium}

When work gets boring, many researchers tune out by tuning in - enduring repetitive work by listening to music or stories.

Deciding what's best to listen to during tedious tasks depends on the kind of work. For tasks that require some attention but not full focus, behavioural ecologist Margaret Couvillon, who will soon teach entomology at the Virginia Polytechnic Institute and State University in Blacksburg, recommends choosing familiar audio books. But to survive long stretches of nothing punctuated by busy periods, she prefers podcasts that are easy to pause and resume. Favourites include: This American Life, Invisibilia, Science Friday and Wait Wait Don't Tell Me.
Adrian Smith, an ant researcher at the North Carolina Museum of Natural Sciences in Raleigh, North Carolina, likes podcasts, too, and recommends ones that match outside interests. He enjoys comedy and pop-culture themes: Bullseye, WTF, the Memory Palace and the Bret Easton Ellis Podcast

Music is another option. David Hadley, an epidemiologist in Tampa, Florida, likes to listen to stuff that's familiar to him. UK neuroscientist Dean Burnett prefers classic mainstream pop that drowns out distractions without being too stimulating. $\mathrm{He}$ also points to a common belief that video-game theme music is ideal for boosting motivation. E.S.
Biologist Karen Warkentin counts frog eggs.

he found what he was looking for: colonies of Formica archboldi, a species that preys on other ants and litters its nests with their carcasses. $\mathrm{He}$ wanted to take them to his lab to study their prey preferences and possible predatory behaviours.

It could always be worse, adds neuroscientist Dean Burnett, who, as a graduate student at Cardiff University, UK, watched many rats navigate many mazes, tallying which direction the rats chose at each turn, to try to understand how they retrieved memories. Without a way to automate data collection, he would remind himself of the glamour of his previous job: embalming corpses for a medical school.

He recommends starting work with your eyes open and the expectation that some tasks will be less fun than others. "People want to do science, and they have big lofty goals," he says. "A lot is day-to-day work. There can't be many jobs that are generally enjoyable all day, every day."

To make monotonous work more bearable, it can also be useful to schedule repetitive tasks to match your own ebbs and flows of energy, says Karen Warkentin, an integrative biologist at Boston University in Massachusetts. To do her work, she has forced herself to stay awake many nights in a dark lab, waiting for snakes to wake up and eat frog eggs. She has walked around a pond counting bundles of dozens of eggs, often recounting and recounting. And she has measured thousands of frogs as they grew from tadpoles to adults, all in the name of understanding plasticity in the early-life stages of amphibians, among other goals. After handling frogs all day, she spent evenings plugging numbers into spreadsheets and checking columns - clocking 16-hour work days in what she calls a "crazy marathon" of an experiment.

She prefers different times for different tasks. For her, early morning is usually best for creative work, such as writing. When her brain feels fried, often after lunch or in the evening, she finds satisfaction in repetitive jobs. "You can feel like, 'Hey, I'm still being productive'” she says.

Warkentin likes to work in silence, but many researchers distract themselves by listening to music, podcasts or books on tape (see 'Tunes for tedium'). Tedious times can also be a bonding experience, Burnham says. While digging 
for dinosaur bones, his field crew chats and jokes around, creating memories and forging friendships. "The best way to endure it is to put together a field crew of people who are like-minded and enthusiastic and really want to be there," he says. "Then you can sit around and have fun."

\section{BUILDING WITH BOREDOM}

Boredom isn't just something to endure: it can carry value of its own, giving the brain uninhibited space to wander and wonder. As a graduate student, Smith had an idea while watching ants (Novomessor cockerelli) move around in a box for hours: what if he reunited a group of isolated worker ants with the queen instead of with the rest of the colony, as he had done in other experiments? The results were surprising: the queen attacked the main worker and rallied the rest of the workers to gang up on it. The discovery spawned two publications: one in the German journal Naturwissenschaften ${ }^{2}$ in 2011, and the other in Animal Behavior ${ }^{3}$ in 2012.

Smith also credits boredom for some unexpected twists in his career. During bouts of daydreaming and podcast-listening while doing menial tasks, he decided to create a series of YouTube videos and launch a podcast, Age of Discovery, in which he interviews biologists about their careers. Developing those multimedia skills helped him to land his current job, which includes outreach and communications. "I spent countless hours thinking about whether I wanted to commit to things that were tangential to my research but turned out to not be tangential to my career," he says. "That stuff wouldn't have happened if I was just occupied in front of the computer writing all the time or whatever."

Boredom can also spark creative ways to minimize it. Frustrated with how long it took to run computer simulations for his software, Hadley more than once boosted his efficiency by rewriting programs created by others. "If you are only doing something once or twice, you can afford to wait a couple of seconds," he says. "When you are doing permutations two million times, that's two million seconds lost. It helps me reduce my downtime."

These kinds of stories are being documented in an emerging field of research on the value of boredom. In one study ${ }^{4}$, Jennifer Hunter, a PhD student at York University in Toronto, and her colleagues found that - after accounting for traits such as extroversion people who are prone to boredom also report being curious types, adding to growing evidence that boredom can breed innovation. "I think it can be a huge catalyst," she says. "Don't ignore your boredom. It can tell you really powerful things about what you're doing."

As a career evolves, boredom can become a state of comfort. Although Warkentin's frog-counting work might sound tedious, she doesn't mind it - instead, she finds it satisfying to be in the natural world and enjoy serendipitous experiences with wildlife. She looks for the same personality fit when fielding applicants for her team. "When I'm recruiting students," she says, "I'm like, 'Does this sound like your idea of a good time?"'

The answer might be 'no', and those feelings are worth paying attention to, says Margaret Couvillon, a behavioural ecologist who recently completed a postdoc at the University of Sussex, UK, and will soon begin teaching entomology at the Virginia Polytechnic Institute and State University in Blacksburg. Couvillon started out as a neurobiology $\mathrm{PhD}$ student, and found herself staring at slices of bird brains. As she slowly inserted probes into the tissue to find neurons, she became discontented. Her true interest was animal behaviour, and she realized that she really wanted to watch animals in action, not study their brains in the lab.

When she transferred to an ecology programme elsewhere, she discovered that her experiments included plenty of tedious elements, too. She has spent "many, many, many hours" watching videos of dancing bees (Apis mellifera) and timing and measuring their movements to determine where they forage. She has also spent a lot of time sitting in front of honeybee feeders, counting insects that visit and waiting for long stretches when none come by. But Couvillon has discovered that she's much happier enduring boring work when it addresses the questions that truly interest her. And with so much of her time taken up by mentally exhausting tasks, she has come to cherish the chance to sit by a honeybee feeder on a nice day. She suggests keeping expectations realistic - after all, nobody has a job that delivers eureka moments every day.

She also recommends shadowing a variety of scientists to see whether the daily reality seems appealing before committing to a speciality. "Not all dirty work is created the same," Couvillon says. "You have to have an everyday life you can handle."

Emily Sohn is a freelance journalist in Minneapolis, Minnesota.

1. Gong, E., Martin, L. D., Burnham, D. A. \& Falk, A. R Proc. Natl Acad. Sci. USA 107, 766-768 (2010).

2. Smith, A. A., Hölldobler, B. \& Liebig, J. Naturwissenschaften 98, 237-240 (2011).

3. Smith, A. A., Hölldobler, B. \& Liebig, J. Animal Behav. 83, 587-593 (2012)

4. Hunter, J. A., Abraham, E. H., Hunter, A. G., Goldberg, L. C. \& Eastwood, J. D. Thinking Skills Creativity 22, 48-57 (2016).

\section{CORRECTION}

The Careers feature 'Visa to visit' (Nature 536, 365-366; 2016) wrongly stated that Kelsey Glennon asked students from indigenous tribes not to stand so close to her. She actually made the request of all her students.

\section{TRADE TALK Star selector}

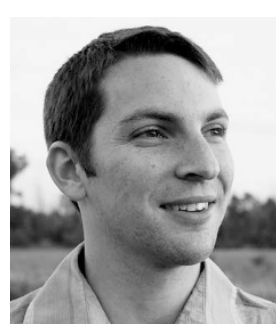

As an astronomy PhD student at Harvard University in Cambridge, Massachusetts, Nathan Sanders learnt statistical modelling to analyse supernova explosions. Now, he works for Legendary Entertainment in nearby Boston, applying those quantitative skills to predict which stars and story lines can make a film into a commercial success.

When did you consider leaving astronomy? I had learned a new computational framework in a statistics course. As I applied those techniques for my thesis, I realized that I loved what I was doing, and the reason had more to do with the statistical models than the astronomy applications. That made me open to new opportunities. I thought I would be doing a disservice to myself if I didn't explore them.

\section{What appealed to you about this position?} When I was hired in 2013, Legendary had just launched its applied-analytics division in Boston. It felt like an opportunity to rethink and reinvent the way that companies pick which films to make and how to build support for them. The goal was to be the first in Hollywood to make decisions on the basis of data and evidence rather than on intuition.

Besides technical skills, what do you look for in candidates when you recruit?

Communication is key. You have to be comfortable with diverse concepts, and talk to business people, filmmakers and technical colleagues.

\section{How did you hear about this position?}

I emphasize the importance of volunteering and getting out into the community. As a firstyear graduate student, I started a project called Astrobites, a collaborative writing project that creates a Reader's Digest version of astronomy literature. I also volunteered with an organization doing live science demonstrations. The executive director was a friend of the chief analytics officer at Legendary Entertainment. It was one of those random connections that so often creates a job opportunity, but that can be hard for scientists to foster if they are completely focused on their thesis work.

\section{INTERVIEW BY MONYA BAKER.}

This interview has been edited for length and clarity. See go.nature.com/2bix $4 y 7$ for more. 